\title{
The Dutch Green Deals Policy and Its Applicability to Circular Economy Policies
}

\author{
Sven Kevin van Langen ${ }^{1,2, *([)}$ and Renato Passaro ${ }^{3(1)}$ \\ 1 International PhD Programme/UNESCO Chair "Environment, Resources and Sustainable Development", \\ Department of Science and Technology, Parthenope University of Naples, 80143 Naples, Italy \\ 2 Supply Chain Department, Olympia Electronics, 60300 Eginio, Greece \\ 3 Department of Engineering, Parthenope University of Naples, 80143 Naples, Italy; \\ renato.passaro@uniparthenope.it \\ * Correspondence: kevin.van.langen@uniparthenope.it or sk.vanlangen@outlook.com \\ or klangen@olympia-electronics.gr
}

check for updates

Citation: van Langen, S.K.; Passaro, R. The Dutch Green Deals Policy and Its Applicability to Circular Economy Policies. Sustainability 2021, 13, 11683. https://doi.org/10.3390/ su132111683

Academic Editors: Jitka Fialova and Martina Zeleňáková

Received: 8 September 2021

Accepted: 16 October 2021

Published: 22 October 2021

Publisher's Note: MDPI stays neutral with regard to jurisdictional claims in published maps and institutional affiliations.

Copyright: (c) 2021 by the authors. Licensee MDPI, Basel, Switzerland. This article is an open access article distributed under the terms and conditions of the Creative Commons Attribution (CC BY) license (https:// creativecommons.org/licenses/by/ $4.0 /)$.

\begin{abstract}
This study investigates the applicability of the Dutch Green Deals policy instrument for use in projects that help the transition towards a Circular Economy in the Netherlands. Green Deals provide an opportunity for firms, NGOs, universities, and provincial, municipal, or waterboard governments to sign an agreement with the national government to take away barriers for a Circular Economy related innovation. Quantitative and qualitative content analysis has been performed, categorizing all green deals as being related to Circular Economy and those are further categorized thematically and analytically. A total of 50 relevant Green Deal agreements are selected for quantitative and qualitative content analyses that cover 9 themes, 20 industry classifications, and 10 types of action undertaken, being particularly popular in the biobased economy and construction industry. The policy instrument is believed to be successful in addressing a variety of barriers and as useful in strengthening national innovation systems, thus, it can be recommended for application in other countries. The instrument does lack clear policy indicators and would benefit from explanatory reviews with each agreement. Future research could compare this policy instrument to similar instruments employed in other EU countries and developing countries, the potential role of green financing for such green deal agreements should also be considered.
\end{abstract}

Keywords: circular economy; public policy; sustainable development; green deals; qualitative content analysis; The Netherlands; European Union; policy instrument; transition barriers; National Innovation System

JEL Classification: O38; P48; Q01; Q28; Q38

\section{Introduction}

The environmental impact of the linear take-make-waste economy has induced societal actors to resolutely turn their attention towards the adoption of sustainable initiatives oriented to the transition to the Circular Economy (CE) paradigm [1]. Institutions, governments, and local administrations are engaged in both creating and enabling appropriate conditions for transitioning towards a circular economy [2-4] as well as in introducing and implementing programs and policy measures aimed at putting the principles of the CE into practice $[5,6]$ by supporting economic and behavioural changes by companies and citizens, thus contributing to the rise of their expectations towards the CE transition. For these reasons, the $\mathrm{CE}$ as tool for triggering a sustainable development process is gaining a lot of attention as of late and has been included in multiple recent EU policies [3-5]. Outside of the EU, the concept of CE has also garnered attention, most notably by the Chinese government that has implemented CE policies since 2002 [7,8], as well as the USA 
and Japan, and also in Latin America various governments have developed CE roadmaps and initiatives.

From the conceptual development point of view, in the last two decades of broad exploration for sustainable development, CE has emerged, integrating previous concepts and practices into a framework oriented to propose a restorative and regenerative economy by intention and design [2]. The CE concept has been mainly addressed to face the environmental and economic aspect of sustainability $[9,10]$ (with interests toward sustainable economic growth, new businesses and job opportunities, and the preservation of natural capital). Thus, in the implementation of $\mathrm{CE}$, the social aspects were little considered with some scholars who identified the cause in the cultural background rooted on a scientific basis (engineering and natural sciences) instead on a social basis [11]. This has subjected the EC to much criticism and has been questioned as a viable solution to the sustainability challenge, given its inconsistency towards important social issues (intra-generational equity, diversity, improved public health, financial and social opportunity equality, etc.) [12-16]. In addition, $\mathrm{CE}$ has been criticized being often framed from an eco-modernist approach in the EU $[8,17]$, which claims to rely on technologies that allow for a decoupling of human development from environmental impacts [18] but focus on growth and competitiveness rather than on the socioecological challenges [19]. While these criticisms have led to increasing attention to the social pillar of the EC over the past decade, scholars argue that still it is unclear whether the EC can promote social well-being for generations to come [20].

To reduce the environmental impacts of production and consumption processes, the EC aims to improve resource and material management, food safety and security, and waste management, as well as to reduce the impact of energy production and consumption [2]. These aims are carried on by recovering materials from waste streams for recycling or reuse, using products longer to minimise material consumption, and increasing the use intensity of goods also through the superior design of materials and products and circular business models [21-23]. For this to happen, more elements are needed, from new legislation and policy framework, new production models and technologies, a system of supporting and infrastructures, new consumption and lifestyle models, etc. [24-28]. Political measures and instruments, by involving all societal actors, play a crucial role in any country to trigger the transition to $\mathrm{CE}$ by leveraging the strong and general focus on a sustainable socioeconomic system [29]. It has been suggested that post-COVID-19 recovery programs are a good opportunity to improve waste management practices, especially by focusing on the health benefits [30]. Investing in biorefineries as part of a post-COVID-19 recovery has good potential for being economically, environmentally, and socially beneficial.

Outside of reducing raw material consumption, CE plays an important role in mitigating biological waste. Bioenergy is increasingly used as an alternative to fossil fuels in electricity production that can help cut GreenHouse Gas (GHG) emissions and solve longstanding issues on dealing with biological waste. The transition to biofuels can be complicated, however, and requires a tight integration with stakeholders [31,32]. Biorefineries have been proven to provide sound environmental benefits over traditional fossil fuel-based refineries [33-37]. The transport sector can also gain from biofuels, specifically by harvesting methane from biological waste, which can be used as a sustainable vehicle fuel [38]. Biowaste can come in the form of agricultural waste, household food waste, and from wastewater sludge [39-42]. The lipids in wastewater sludge are an especially interesting method of creating biofuels through anaerobic digestion, creating both a sustainable fuel and saving costs on wastewater purification. There has to be a good supply of biowaste or you risk having to use first-generation feedstock. A proper knowledge flow is crucial to the success of biofuel exploitation, and government-funded strategic networks can play an important role in facilitating this process, leading to further b2b networking [43].

The Green Deals policy instrument addressing the implementation of the transition to the CE is analysed in this article, which focuses on the case of the Netherlands and can represent a best practice to be adopted in other EU national realities. In the Netherlands, the Circular Economy CE is expected to bring both environmental and economic benefits 
by being at the forefront of (technical) innovation. In late 2012, a new government was inaugurated in the Netherlands that, for the first time, made Circular Economy a key policy area. In 2016, the same government pledged to reduce primary material consumption by $50 \%$ in 2030 and to have completed the transition to a Circular Economy by 2050, making it a key component of their strategy to become carbon neutral [44].

The Dutch national government created a policy instrument in 2011, named the Green Deals', that aims to provide a communication channel between firms and other stakeholders for projects, aimed to make the Dutch economy greener and more sustainable $[45,46]$. It is a policy instrument created within the larger 'Groene Groeibeleid' (green growth policy) aimed at improving the Dutch economy with environmentally friendly practices, including, in addition to the Green Deal instrument, also a wider group of sustainabilityoriented measures on electrifying transport, supporting sustainable entrepreneurship, and transforming to a biobased economy, amongst others according to the progress report on the Green growth policy, published on 11 March 2016 at https: / / www.rijksoverheid.nl/ onderwerpen/duurzame-economie/documenten/kamerstukken/2016/03/11/kamerbriefover-voortgangsrapportages-groene-groeibeleid (accessed on 8 October 2021). Whilst initially it creates some push from the government, the outcomes of the policy instrument are expected to create more business pull according to the National Program Circular Economy, published on 14 September 2016: https: / / www.rijksoverheid.nl/documenten/rapporten/ 2016/09/14/bijlage-1-nederland-circulair-in-2050 (accessed on 8 October 2021). While initially the policy instrument was mainly set up to create green economic growth, overtime, its use became adapted to the Dutch government's goal to achieve a CE by 2050 according to the National Program Circular Economy and became one of the cornerstones in kicking off this transition according to the Government response to transition agendas for the Circular Economy, published on 29 June 2018: https: / / www.rijksoverheid.nl/documenten/ kamerstukken/2018/06/29/kabinetsreactie-op-de-transitieagenda-s-circulaire-economie (accessed on 8 October 2021). The CE program by the Dutch government is also linked to the government's strategy to reduce carbon emissions according to the report on the effects of the national program Circular Economy and transition agendas on greenhouse gas emissions, published on 29 May 2018: https: / / www.rijksoverheid.nl/documenten/rapporten/2018/05/29 /effecten-van-het-rijksbrede-programma-circulaire-economie-en-de-transitieagenda-s-opde-emissie-van-broeikasgassen (accessed on 8 October 2021).

Green Deals are mainly made in industries that are considered critical and of high priority by the Dutch government, the industries responsible for $75 \%$ of Dutch $\mathrm{CO}_{2}$ emissions, and can also be found in smaller sectors of the Dutch economy. This can be achieved through subsidies but also by setting up public research initiatives and, as often happens, through changes in regional and/or national laws. The aim is to foster innovations and not only help the environment but create a technological leadership in sectors important to the Dutch economy. In 2012, a year after the first implementation of the policy, 146 firms had made a Green Deal agreement [46]. To date (December 2020), there have been 232 Green Deals, of which 179 have been finished and 53 are still being executed.

The applicability of the Green Deals policy instrument for the CE has not yet been studied in academic literature to the best of our knowledge. In fact, although there have been several documents by the Dutch government or one of its organizations to evaluate the policy instrument, only one report specifically looked at the instrument's suitability for the Circular Economy [47]. This is of paramount importance, given that the EU's new Circular Economy Action Plan is one of the main building blocks of the European Green Deal, which represents the EU's new agenda for sustainable growth for the next decades [48]. In this view, the aim of this paper is to shed light on the policy initiatives of the Dutch government to support the CE transition. In particular, we analyze the features of the Green Deal policy measures to comprehend the directions and the ways they are influencing the practical implementation of the CE initiatives and how this corresponds to related academic literature on CE and economic development. We aim to provide a better understanding of in what themes (e.g., bioeconomy) and industries the policy 
instrument is mainly used, what typical outcomes by the Dutch government are achieved, and how (regulatory/policy) barriers in the transition to a CE can be overcome. Thus, our research question is: How is the Dutch government using Green Deals as a policy instrument that aids Circular Economy innovation? To achieve this, we perform a full text (quantitative and qualitative) analysis of the documentation publicly available on all Green Deals identified as relevant to the CE. As there are many definitions of CE, 114 different ones within academia have been found in a 2017 study [49], we would like to specify that we consider the practice of reusing products or materials as a key part of the CE. We do not, for this study, include incineration, as resources are lost from the economy in these processes. This last reflection, which ideally separates the different phases of the transition to the $\mathrm{CE}$, should be considered in the analysis of the transition from the linear economy to the recycling economy and then to the $\mathrm{CE}$ [50].

After this introduction, we provide a background section, reviewing the literature on $\mathrm{CE}$ and national innovation systems and how this policy instrument fits in. Then, a research question and methodology section will detail what is conducted in this study. A results section will form the core of this paper and details the outcomes of the quantitative and qualitative content analyses that were performed. Then, in the next section, we discuss the results and address the ways to implement the policy under consideration. The conclusion section summarizes the result and illustrates the limits as well as the implications of this study.

\section{Materials and Methods}

\subsection{Theoretical Background}

In the last decades, the Circular Economy is gaining a lot of attention both from the policy and research point of view. Many policy initiatives and actions have been adopted at the EU level $[48,51,52]$. Scholars also observe Circular Economy as a field of knowledge and a set of policy initiatives and tools [53-55], aimed to lead the global economy in the challenge toward a sustainability transition. This is carried out by promoting the change from linear to circular production and consumption patterns and preventive solutions for slowing, closing, and narrowing material and energy loops [13,56,57]. Even though this transition can be put into practice by means of different perspectives and scenarios [58], generally speaking, the Circular Economy stresses the need for reducing pressure on natural resources to preserve and enhance natural capital [59]. Urban and industrial systems have a high metabolism of material and energy flows, often measured through material or substance flow accounting, imported from ecosystems, and are capable of a productive circularity enabled by transitioning to a circular economy [60]. They thus stand for a promising avenue for closing materials loops within a national circular economy program.

It has been identified for a while that innovation is key to economic growth $[61,62]$. Innovation does not just create economic growth. Sufficiently great innovations can lead to instability and turbulence [63], and this can aid well if you attempt to replace your linear economy instead of just supplementing it through a rebound effect, as Circular Economy policies often aim to achieve. For countries to foster innovation, it is important to foster a National Innovation System (NIS) where systematic forms of cooperation and networking are developed between different actors (public/private, large/small, local/national) who contribute to the improvement of the innovation processes $[64,65]$. This calls to not just innovate but to work on a country's education and infrastructure systems as well to gain benefits from socioeconomic development and to create more innovation [66]. Bringing companies together in clusters benefits their adaptability to the local situation [67] but also strengthens them on global markets, making it an important part of fostering innovation [68,69]. In fact, there is an increased call for open innovation, where knowledge inputs are not limited to a firm's bounds. This has been found especially usefully for service-based companies and manufacturing companies that implement service business models around their physical product offerings, which is also important to the Circular Economy [70,71]. Especially for SMEs, the proper integration of a business network 
and users, as well as institutional support, is critical in enabling innovation, as they do not often have all the tools to successfully innovate themselves [72]. Transitioning to a Circular Economy process or business model requires innovation that faces some very specific barriers $[73,74]$. Scholars have categorized these barriers in four groups, technological, financial, cultural, and regulatory/policy barriers [75,76].

Especially related to policy, there are typically regulatory barriers to trading waste and, even if it is possible, this is often blocked by hard to acquire permits, and there is uncertainty about future policies [77]. Other relevant barriers identified by Henriques et al. (2021) [77] are an instable demand for circular products, a lack of financing (both private and public), and a lack of knowledge on available solutions, complemented by a lack of intermediaries that enable communication and set up networks for innovation. In the case of using recycled products, governments can take away barriers by sharing information, settings standards, preferring recycled products in green public procurement, and by stimulating the market [78]. In combatting barriers, governments have to adopt a mix of instruments covering items such as command and control, market-based instruments, and voluntary programs and communicate to managers how it "pays to be circular" [79].

The Dutch Green Deals policy instrument shows good potential to aid both SMEs and other stakeholders in promoting the transition to a Circular Economy, in part through new initiatives and innovations. If you measure the policy instrument against innovation theory on economic development and system change, it is quite promising. They share a focus on green and sustainable development and mainly try to overcome barriers in communication (between businesses and the public sector as well as between businesses themselves and communication to the general population) and local regulations in addition to the more typical subsidies and grants [46]. The OECD (1997) noted that strong National Innovation Systems are primarily built by strong knowledge flows between businesses and between the private and public sector. The Green Deals policy instrument caters to both these knowledge flows, while initially with knowledge flows between the private and public sectors; it aims to be a start of more business-to-business knowledge flows that will take over once the instrument has done its job. To create a National Innovation System, governments should fund R\&D and have public research institutes cooperate with firms in joint technology projects, contracting specific research and educating the training of new researchers [65]. The Green Deals policy instrument especially aims to create such joint technology projects directly by setting up such projects or by creating a market for it through public procurement. It is only a small part of a nation's firm that introduce radical innovation, as is required for a radical concept such as Circular Economy, and especially for governments, there is a role in supporting the technological infrastructure required [80]. If a stable strategy (e.g., the linear economy) exists with the National Innovation System's innovators, government intervention forms a good way to enhance the system [81]. Governments have to support these radical innovators and increase their number until a self-sustaining transition to the desired new equilibrium is achieved. National government support plays an important role in developing more diverse technological research streams and breakthrough innovation [82].

\subsection{Research Question and Methods}

For this research, the state-of-the-practice of the Dutch Green Deals policy instrument, specifically relating to innovation in the Circular Economy, is studied to bring this policy instrument into the academic discourse. The research question is: How is the Dutch government using Green Deals as a policy instrument that aids Circular Economy innovation?

To this end, after an analysis of the research on the transition to the Circular Economy, aimed to frame the results of this study in an interpretative framework where they can be further studied and adapted, a quantitative and qualitative content analysis of the reports issued about the separate Green Deal agreements is performed. The agreements' literature is collected directly from the Dutch Enterprise Agency, part of the Ministry of economic and Environmental Affairs, through their portal on https:/ / www.greendeals.nl/english 
(accessed on 8 October 2021). All Green Deal agreements are filtered for their relevancy to the Circular Economy based on their abstracts to filter out Green Deals that mainly address issues not related to the Circular Economy, then a full-text analysis of the selected Green Deal agreements follows. Through the full-text analysis, trends are identified which show the themes and industries with the most Circular Economy related Green Deal agreements and how the policy instrument is used by the national government to achieve Circular Economy innovation.

We use quantitative and qualitative content analyses in this study. Content analysis is selected as it is a commonly used and well tested method [83,84]. This method is known as good method to replicate inferences from texts in light of a specific context [85]. Quantitative and qualitative content analysis is especially useful in social science research as it can describe social phenomena and be tailored for specific (sub) questions. Using codes and category content from one or multiple reports can be efficiently structured and analyzed. For this paper, we have specifically chosen factual categories, thematic categories, and analytical categories as the most suitable category types. Factual categories are those that contain objective and specified data. Thematic categories are those that refer to certain well-established topics. Analytical categories form after an intensive data analysis and are more suitable for topics that are conceptual and not yet well established. After all relevant documents are read, suitable categories are established, and the data is assigned to these categories. Once all data is categorized, these results can be analyzed to draw new conclusions and present novel information. Categorization can be conducted either empirically or conceptually. If a conceptual category is formulated on the basis of a large quantity of data, it is a good practice to provide a short narrative summary to provide an intermediate level between the categorization and the large body of original text [83]. Care has to be taken to not consider too many categories as this might take away from the depth of what the researcher wants to study specifically; it is important to stay concise [86].

For the abstract analysis of the Green Deals, we performed a simple quantitative content analysis marking for empirically established factual categories, marking papers as being mainly related to Circular Economy or not and if the agreements specifically mention Circular Economy or not, categorized by the year in which the agreement was made. The results of the abstract analysis and the factual categorizations is provided in Section 3.1. For the full-text analyses, we used quantitative content analyses to empirically establish thematic categories such as which theme(s) or industry an agreement belongs to, based on categories also used by the Dutch government. This part of the full text analysis and thematic categorizations is provided in Section 3.2. To categorize the government actions taken, as part of the Green Deals related to Circular Economy, we used a qualitative content analysis and chose conceptually established analytical categories based on recurring actions that we identified during our latent analysis. This part of the full text analysis and the analytical categorizations are provided in Section 3.3. For the analytical categorizations, short narrative summaries are provided with each category to provide a better understanding of how the categories differ and what type of actions fall under each category. An overview of steps taken is provided in Figure 1.

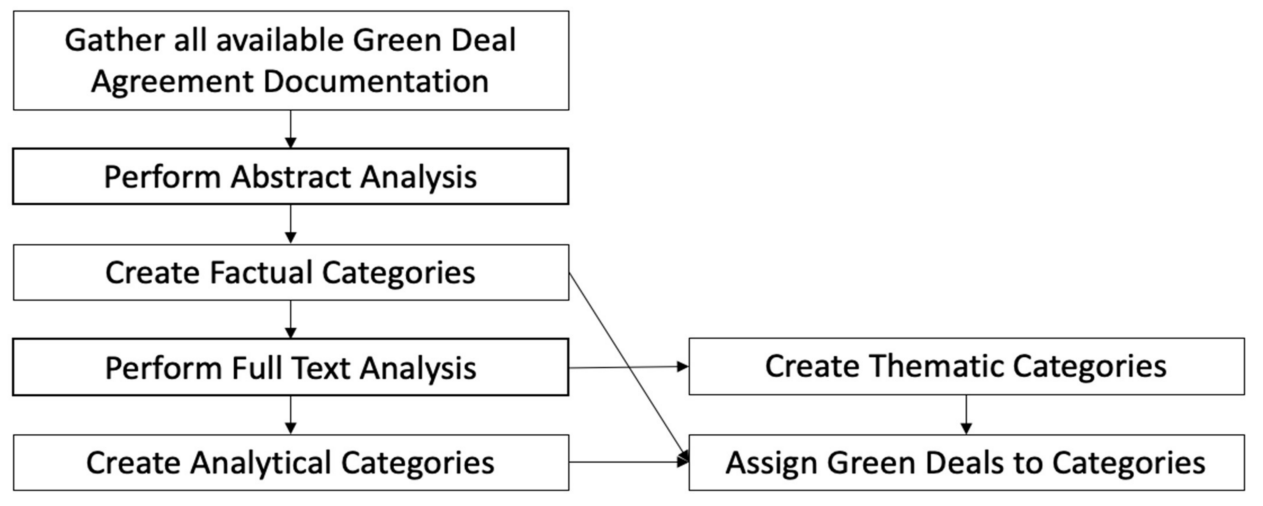

Figure 1. Overview of steps taken to analyse the Green Deal Agreements. 


\section{Results}

\subsection{Number of Agreements Related to Circular Economy}

The first action taken was to analyze the abstracts of all Green Deal agreements publically available to filter out those agreements not related to the Circular Economy, the results of which can be found in Table 1. As of 2021, in total, 50 Green Deal Agreements were found that are related to Circular Economy of a total of 232 Green Deal Agreements overall. Of these 50 Green Deal agreements, 35 were finished and 26 had published a final report with results. Some projects marked as in progress still released a final report, as their process refers to measures staying in place temporarily, but there will not be further action taken in these projects.

Table 1. Number of Green Deal agreements related to the Circular Economy, sorted by year.

\begin{tabular}{cccccc}
\hline Year: & $\begin{array}{c}\text { Total } \\
\text { Agreements: }\end{array}$ & $\begin{array}{c}\text { Agreements } \\
\text { Related to Circular } \\
\text { Economy: }\end{array}$ & $\begin{array}{c}\text { \%of Agreements } \\
\text { Related to Circular } \\
\text { Economy: }\end{array}$ & $\begin{array}{c}\text { Specific Mention of } \\
\text { Circular Economy }:\end{array}$ & $\begin{array}{c}\text { \% of Specific Mentions } \\
\text { of Circular Economy }\end{array}$ \\
\hline 2011 & 75 & 9 & 12 & 0 & 0 \\
2012 & 71 & 11 & 15 & 0 & 3 \\
2013 & 13 & 9 & 69 & 3 & 43 \\
\hline 2014 & 18 & 7 & 39 & 1 & 25 \\
2015 & 16 & 4 & 25 & 0 & 0 \\
\hline 2016 & 15 & 1 & 7 & 2 & 50 \\
2017 & 11 & 4 & 36 & 2 & 100 \\
2018 & 10 & 2 & 20 & 0 & 100 \\
2019 & 4 & 2 & 50 & 13 & 0 \\
\hline 2020 & 1 & 1 & 100 & 26 \\
\hline Total: & 232 & 50 & 22 & 26 \\
\hline
\end{tabular}

* specifically mentioning 'circular/circulair/circularity/circulariteit' in the title or abstract.

Notably, over half of all Green Deal Agreements were made in 2011 and 2012, yet this only resulted in $40 \%$ of the Green Deal Agreements that are related to Circular Economy in any way. In fact, these years had the lowest percentage of Green Deal Agreements related to Circular Economy overall, save only for 2016. It is notable that in 2013, there seems to suddenly be a sharply increased interest in Circular Economy, with 9 out of 13 Green Deal Agreements covering Circular Economy in that period. This can be explained by the Dutch government making Circular Economy a prime policy area in late 2012, when a new government was formed.

While the years 2011 and 2012 had 40\% of the Green Deal Agreements that are related to Circular Economy, none of these projects specifically mention Circular Economy or a directly related term in their title or abstract. Terms such as 'closing the material loop' and the 3Rs were used instead. The mentioning of 'Circular Economy' only happened from 2013 and onwards, after a new Dutch government made Circular Economy a prime policy area. In 2017 and onwards, the inclusion of the Circular Economy term seems to take a further rise (see Table 1).

Green Deal projects seem to be mainly concentrated around the biggest industrial cities of the Netherlands and less so in rural regions. This could mean that the adopted Circular Economy approach of the Dutch Green Deal Agreement is probably mainly oriented towards societal metabolism at industrial and urban levels. See Figure 2 for an overview. 


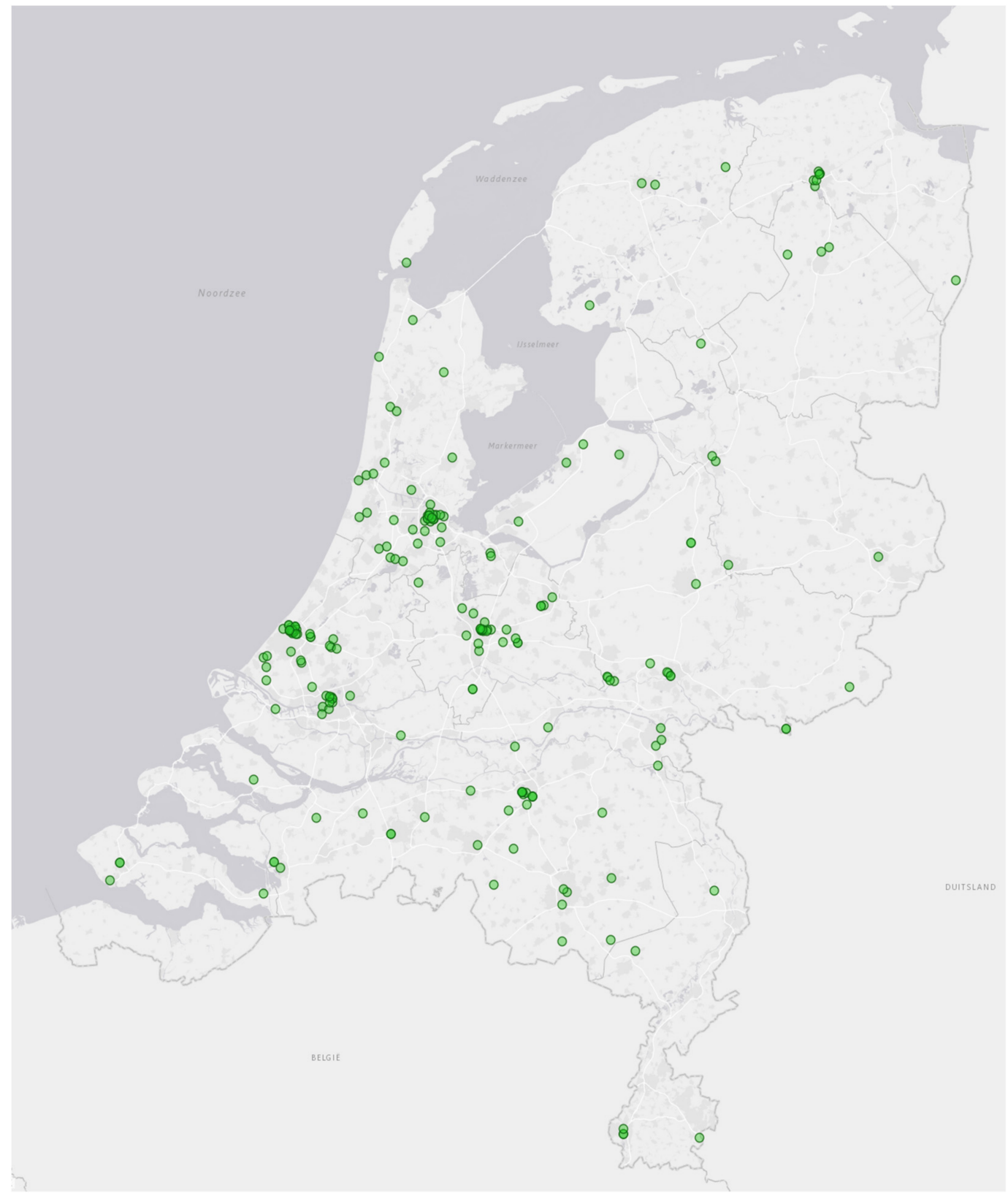

Figure 2. Geographical distribution of Green Deal agreements throughout the Netherlands.

\subsection{Themes and Industries of the Green Deals}

The Dutch government has classified every Green Deal agreement as belonging to one or more themes and one specific industry. An analysis was performed to find out how many Circular Economy related Green Deal Arrangements were in each theme, as can be seen in Table 2, and in each industry, as can be seen in Table 3.

The results in Table 2 show that the majority of Green Deal agreements related to Circular Economy are themed under resources, with 35 out of 50 arrangements falling under that theme. In addition, the themes of Biobased Economy, Construction, and Energy have a relatively large amount of Circular Economy related projects (respectively 14, 8, and 13). It has to be noted that a project can fall under multiple themes. Climate and Water show higher a higher percentage than Energy and Construction, showing that climate and water are more Circular Economy relevant themes than Energy and Construction in green policy. 
Table 2. Number of Circular Economy related Green Deal Agreements per theme.

\begin{tabular}{cccc}
\hline Theme: & Total: & CE Related: & \% CE Related: \\
\hline Biobased Economy & 67 & 14 & 21 \\
Biodiversity & 42 & 3 & 7 \\
Construction & 46 & 8 & 17 \\
Energy & 135 & 13 & 10 \\
Resources & 62 & 35 & 56 \\
Climate & 10 & 2 & 20 \\
Mobility & 35 & 2 & 6 \\
Food & 27 & 3 & 11 \\
Water & 17 & 3 & 18 \\
\# of Green Deals & 231 & 50 & 22 \\
\hline
\end{tabular}

Table 3. Number of Circular Economy related Green Deal Agreements per industry.

\begin{tabular}{ccc}
\hline Industry/Field: & Total CE Related Agreements: & \% of Total CE Agreements \\
\hline Agriculture & 3 & 6 \\
Chemicals & 2 & 4 \\
Construction & 9 & 18 \\
Electronics & 2 & 4 \\
Entertainment & 2 & 4 \\
Food & 1 & 2 \\
Fishing & 1 & 2 \\
Forestry & 1 & 2 \\
Health Care & 1 & 2 \\
Metallurgy & 1 & 2 \\
Vehicles & 1 & 2 \\
Plastics & 2 & 4 \\
Railways/Trains & 2 & 4 \\
Shipping & 1 & 2 \\
Textile & 2 & 4 \\
Waste & 2 & 4 \\
Water & 4 & 8 \\
Multi/labelling & 5 & 10 \\
Multi/Procurement & 2 & 4 \\
Multi/Other & 4 & 8 \\
Total & 50 & 100 \\
\hline
\end{tabular}

Projects related to the Circular Economy are quite evenly spread over industries, as can be seen in Table 3. Only the construction industry has a significantly higher number of projects than the other industries, having 9 out of 50 projects. The combined industry of agriculture, forestry, and fishing covers $10 \%$ of the agreements. Of the projects labelled as belonging to multiple industries, four are directly related to labelling, and two projects are related to procurement.

\subsection{Government Action Resulting from Green Deals}

All Green Deal agreements require several actions to be taken by the Dutch national government. In nearly every Green Deal, the government provides a contact person from one of its ministries or other governmental organizations and often manages the network of all involved parties in the Green Deal agreement. A summary of which other topics can be found in any specific Green Deal agreement related to the Circular economy are presented below, and in Table 4 provides in how many Green Deals each type of action was encountered. 
Table 4. Topics regarding what the green deal agreements require from the national government.

\begin{tabular}{ccc}
\hline Topic & Relevant Green Deal Agreement (By Number) & Total \\
\hline Explain Circular Economy itself & 6 & 1 \\
Waste separation initiatives & 11,28 & 2 \\
Create awareness & $15,28,72,109,112,118,119,142,153,156,157,160,166,170,171$, \\
Create industry agreements & $178,180,184,218,228,232$ & $30,76,141,174$ \\
Change regulation and/or policies & $57,67,72,82,86,116,141,144,147,154,156,158,160,163,168,174$, \\
Change procurement requirements & $186,218,223,226,231$ & 21 \\
Set standards & $87,118,131,149,154,199,209,223$ & 8 \\
Support/develop circular cities & $109,153,180,187$ & 4 \\
Share information on available & $168,184,216$ & 3 \\
national/European funding & $30,82,86,87,112,148,156,157,158,163,166,168,170,171,174$ & 15 \\
\hline
\end{tabular}

- Explain Circular Economy itself and Waste separation initiatives.

The first Green Deal agreement related to the Circular Economy tries to provide more clarity on the Circular Economy itself. It aimed to study the economic effect of increased recycling rates for the Netherlands, concluding that it was a positive effect. Other early Green Deal agreements focus on initiatives to separate municipal waste streams.

- Create awareness.

Nearly half of the Green Deal agreements related to the circular economy (21 out of 50) task the government with spreading awareness of Circular Economy concepts. Though generally described quite vaguely, it can take many forms. The scope can range from the local level and within the network of that specific Green Deal agreement to spreading awareness on a European level. The topics can cover a broad range as well, such as spreading awareness on specific circular economy practices but also the distribution of the final results of a Green Deal agreement after its conclusion.

- Change regulation and/or policies.

Another topic that came back in 21 Green Deal agreements was for the government to change regulation so as to remove encountered barriers or drive innovations that aid the transition to a Circular Economy. Rarely, the laws to be changed are exactly specified, but often, the topic that faces a barrier is. At times it is not the national government itself that has to change regulation, but they are tasked to mediate with or coordinate between provincial governments or waterboards.

- Create industry agreements.

Four green deal agreements aim to set industry-wide agreements. This can be to set industry-wide targets on achieving certain goals, such as $\mathrm{CO}_{2}$ reduction, or simply setting up a network. Another four Green Deal agreements specifically try to develop and/or push newly developed standards or labels in an industry.

- Change procurement requirements.

Changing procurement requirements from the national or local governments is another recurring theme that was found in eight Green Deal agreements. This typically involves a call to the governments and government agencies to consider setting a minimum amount of recycled or biobased materials that are to be required to win the bid or to at least assign some weight to such criteria.

- Support/develop circular cities.

The city of Rotterdam comes back in two Green Deal agreements that try to make work of turning Rotterdam into a so-called 'circle city', a city with a tightly integrated circular economy. In addition, the remote underdeveloped Caribbean Island of Saba has a Green Deal agreement aimed at making the island transition into a circular economy. Small developing islands have been identified as benefitting from specific actions that follow an agreed framework and with good coordination, making the Green Deal instrument highly suitable to these regions of the Kingdom of the Netherlands [87]. 
- Share information on available national/European funding.

Finally, there are the green deal arrangements that ask the government to provide information on suitable subsidies for a project that becomes available, both national and EU subsidies. Indeed, this is something Dutch companies and local governments often fail to access [88]. Fifteen Green Deals incorporate this as part of the actions to be taken by the national government.

\section{Discussion}

The results show that the Green Deal Agreement policy instrument is used quite broadly to develop a circular economy in the Netherlands. It is used in many industries and for a variety of purposes. Though at the start of the policy, in 2011 and 2012, it saw most agreements being made, it was after the Circular Economy became a new prime policy area from late 2012 onwards that a large share of the Green Deal agreements was related to the Circular Economy. This suggests it is a flexible policy instrument that is well suited to aid a national government's Circular Economy strategy. Furthermore, we noticed that many Green Deals focused on reducing landfill and waste exports by incineration, but these often do not aim to reintroduce products/materials back into the economy and have therefore been excluded by this Circular Economy oriented analysis. Other examples of excluded agreements were those aiming to improve biodiversity or optimize infrastructure for mobility. The Green Deal agreements tend to centre around urban areas, especially in the more industrialized regions of the Randstad and the Brabantse Stedenrij metropolitan regions, likely because in these areas there is a pre-existing close proximity of potential agreement partners and a higher density of stakeholders. This is in line with research showing that urban areas have the most potential for a circular economy transition [60], nonetheless, important gains can also be made in agricultural land, especially in the area of biorefineries [33-37] and biofuels [39-42].

Relatively many Green Deal agreements task the national government with creating awareness of the results from a Green Deal agreement and for sharing information on available national/European funding, drawing on the networks and expertise of the national government [67-69]. As CE is a field of knowledge on complex systems, these seems an appropriate strategy [53-55]. Looking into regulation and/or policy changes and changing procurement requirements to support the Circular Economy are popular actions that require changes from the national government. Notably, only three Green Deal arrangements are specific for a city or island, though this could be explained with local governments having adequate powers to operate already. The high number of Green Deal arrangements that were related to water often had mainly the Dutch water boards as co-signatories, while in other sectors, there is often a high share of non-governmental signatories (both for-profit and non-profit organizations can be found). This could indicate that water boards lack the proper mandate to adequately address issues relating to a transition towards a Circular Economy in their areas.

Relatively few Green Deal agreements are being made in recent years, for which we have not been able to find an explanation (except the exhaustion of the action of a novelty effect). Though the COVID-19 pandemic might explain why 2020 has seen only one Green Deal agreement published for 2020, 2019 already saw very few Green Deal agreements with just four. However, the instrument could gain new life if it is used as part of a post-COVID-19 recovery plan. Handling waste streams is important in government recovery plans [30], as it can lead to a better public health and reduce the size of informal economies. While the Netherlands does not have a large informal economy, through waste exports it can fuel them in other countries, and the pandemic has shown that public health is a global responsibility.

This study looks at if and how agreements are related to achieving a Circular Economy but does not judge the quality of the agreements. In general, we recognize that Green Deals are used as an instrument to foster cooperation between different actors of the socioeconomic system, which is important in driving innovation [73-76]. In fact, several of the 
14 critical dimensions to SMEs' innovation capacity, as identified by Pierre and Fernandez (2018), are reflected in most Green Deals. Especially the dimensions of network and user integration, as well as institutional support, are reflected in all Green Deals creating a network with one or more governments and a group of stakeholders. Furthermore, in the dimension to implement standards and regulations also served by this policy instrument, many of the Green Deals forge an agreement on setting up new and improved standards as well as to change regulations that block innovation necessary for implementing aspects of the Circular Economy. Promoting such innovation is important when you consider the economic dimension of CE, as innovation is a key factor to GDP growth [61,62].

Most agreements focused on recycling according to our perception from this analysis, the same was also concluded by a government evaluation in 2016 [47]. While recycling is not always the most environmentally friendly circle in the Circular Economy concept. Although this problem is not specific to this policy instrument, it recurs in Circular Economy policies all over Europe [89]. Nonetheless, it is important to study how to refocus Circular Economy policies from recycling to reuse. The government should push for more innovation in these areas as that is the best method to replace the linear economy with the CE [63].

Judging by the actions to which the Dutch government committed itself in the Green Deals, the policy instrument does seem to address many of the barriers identified in the literature. While no agreement really addresses all of the barriers highlighted in the literature (technological, financial, cultural, and regulatory/policy barriers) [75,76], nearly all are covered in at least a few of the Green Deals. Through public procurement commitments, a market is created, regulatory barriers are taken away, and nearly every Green Deal promoted communication and often network forming. In some cases, financing is available, or there will be better communication about financing opportunities. So far green financing does not seem to be used with this policy instrument. The instrument could benefit from being updated to include provisions that the government can issue green bonds that will be used to finance green deal agreements, considering green bonds are increasingly in demand and can offer beneficial interest rates [90-93]. Firms themselves can also be motivated to attract green financing through the Green Deals. For many firms, it is a new concept, and the government can play a facilitating role in acquiring such financing. Green deals in the Netherlands can also be financed through post-COVID-19 recovery funds available to EU countries such as the Netherlands.

A factor that presumably explains the success of the initiative could be the effect determined by the collaboration and cohesion that the various stakeholders, coordinated by the government through the Green Deal agreements, find towards the achievement of shared objectives such as sustainability and the circular economy. For this reason, we believe that other countries would benefit from implementing a similar policy to promote the transition to a Circular Economy, though, depending on the context of a country, they might have to focus on different aspects. Developing countries often have less regulations limiting the use of waste, but instead need a stronger focus on creating knowledge networks and gaining access to funding, for example. While a lack of clear policy indicators and the often-experimental nature of the agreements make it hard to show advantages with quantitative data, common barriers faced also by other countries have been taken away through this instrument. Furthermore, the increased cooperation between governments, universities, NGOs, and the private sector should strengthen National Innovation systems.

\section{Conclusions}

By systematically analysing the Dutch Green Deals policy instrument, we bring this policy instrument into the academic literature so it can be further studied and adapted for other parts of the European Union and the rest of the world. According to an abstract analysis, $22 \%$ of the Green Deal agreements were related to the Circular Economy, which formed the basis for analysing the full body of public documentation available on the agreement. Though it was only starting from 2013 and onwards that the term Circular Economy came into fashion, as Circular Economy became a prime policy area with the 
inauguration of a new government in late 2012, projects related to the concept have been identified from the inception of the policy instrument in 2011.

The policy instrument is used in a broad range of industry categories, the analysed agreements are classified into 20 different industry categories. The most represented industry is construction, with $16 \%$ of agreements falling under this industry and the water industry is a runner-up with $8 \%$ of the agreements. The Dutch government chooses to group the agreements by 10 self-defined themes instead of industries, with an agreement often being part of several themes. The resources theme contains $56 \%$ of the agreements, while the themes water, construction, climate, and biobased economy have around $20 \%$ of agreements each, and the remaining themes have only a few agreements linked to them. All agreements task the national government with having a contact person within a relevant ministry or other government organization for the signatories of the green deal and most ask for the national government to lead a network of the signatories. This seems to follow the line of recent innovation theory that increasingly emphasizes the importance of cooperation and networks [80,81]. A high number of deals also aims to leverage the expertise and network that the national government has, to spread awareness of an agreement's outcomes and to gather information on possible subsidies for example. A majority of agreements try to use the executive power the government has, e.g., by having regulations, policies, and/or the government's procurement standards changed to better suit a Circular Economy. This all helps to face barriers commonly encountered in the transition to a Circular Economy, barriers faced not just by the Netherlands but by many countries, and helps strengthen the National Innovation System, making it recommendable for other countries to adopt a similar policy.

A clear limitation is that the policy instrument does not come with a clear set of policy indicators, nor with a proper review of individual agreements once agreements are finished. Future studies could evaluate the agreements on such factors as success rate or the value to the environment, economic development, and/or society. They can also look in more dept into Green Deals through case studies with a deal's participants to further both Circular Economy research and research on innovation. In addition, comparative studies with other policies and initiatives that aim to achieve similar goals could be performed in a future study, for example, with the policy instrument in Flanders that bears the same name [94]. Furthermore, a limitation of this study is the explorative nature of the research and the fact that only publicly available documentation was studied. Future research could attempt to do explanatory research through interviews or by surveying Green Deal agreement participants. Other promising avenues of future research would be to look at the instrument's applicability to developing countries, whom typically have less regulations related to waste but are typically more lacking in knowledge networks and financing. We often see that the Dutch government is involved in creating knowledge networks and to help look for appropriate funding at the national and international level through this policy instrument and developing countries could benefit from focusing on these aspects.

The Green Deals do speak of financing but rarely of green financing. A promising policy recommendation could be to have the government disburse money from green bonds through green deal agreements. Green bonds are an increasingly attractive investment vehicle and could allow the Dutch government to borrow money towards achieving their environmental goals at a low interest rate. Furthermore, the instrument can be used as part of the government's post-COVID-19 recovery plans.

From these results, further government and corporate policies and implications can be derived. The former should lead local and national governments to strengthen the cooperation approach both within the public administration system and with external actors and stakeholders. This requires the assessment of management and administrative procedures and skills from the perspective of inter- and intra-organizational cooperation. The latter should involve companies from the most represented sectors (construction and water) that can play a leading role in stimulating their partner companies in different sectors in the adoption and exploitation of the opportunities of the Green Deal agreements. 
These actions would contribute to strengthen the effectiveness of the Green Deals as a policy instrument to support the transition to the Circular Economy.

Author Contributions: Conceptualization: S.K.v.L.; methodology: S.K.v.L.; validation: S.K.v.L.; formal analysis: S.K.v.L.; investigation: S.K.v.L.; resources: S.K.v.L.; data curation: S.K.v.L.; writingoriginal draft preparation: S.K.v.L.; writing—review and editing: S.K.v.L., R.P.; visualization: S.K.v.L.; supervision: R.P. All authors have read and agreed to the published version of the manuscript.

Funding: This research has received funding from the European Union's Horizon 2020 research and innovation program under the Marie Skłodowska-Curie Innovative Training Networks (H2020MSCA-ITN-2018) scheme, grant agreement number 814247 (ReTraCE project).

Conflicts of Interest: The authors declare no conflict of interest. The funders had no role in the design of the study; in the collection, analyses, or interpretation of data; in the writing of the manuscript, or in the decision to publish the results.

\section{References}

1. De Mattos, C.A.; de Albuquerque, T.L.M. Enabling Factors and Strategies for the Transition toward a Circular Economy (CE). Sustainability 2018, 10, 4628. [CrossRef]

2. Ellen MacArthur Foundation. Towards the Circular Economy Vol. 1: An Economic and Business Rationale for an Accelerated Transition; Ellen MacArthur Foundation: Cowes, UK, 2012. Available online: https:/ / ellenmacarthurfoundation.org/towards-the-circulareconomy-vol-1-an-economic-and-business-rationale-for-an (accessed on 8 October 2021).

3. Silvestri, F.; Spigarelli, F.; Tassinari, M. Regional Development of Circular Economy in the European Union: A Multidimensional Analysis. J. Clean. Prod. 2020, 255, 120218. [CrossRef]

4. Hartley, K.; van Santen, R.; Kirchherr, J. Policies for Transitioning towards a Circular Economy: Expectations from the European Union (EU). Resour. Conserv. Recycl. 2020, 155, 104634. [CrossRef]

5. Bacova, M.; Bohme, K.; Guitton, M.; Herwijnen, M.; Kallay, T.; Koutsomarkou, J.; Rok, A. Pathways to a Circular Economy in Cities and Regions; Interreg Europe Joint Secretariat: Lille, France, 2016.

6. Romano, O.; Matsumoto, T.; Beck, B.; Thompson, M.; Fath, B.; Liu, W. Cities and the Circular Economy; OECD: Paris, France, 2020.

7. Yuan, Z.; Bi, J.; Moriguichi, Y. The Circular Economy: A New Development Strategy in China. J. Ind. Ecol. 2006, 10, 4-8. [CrossRef]

8. Genovese, A.; Pansera, M. The Circular Economy at a Crossroads: Technocratic Eco-Modernism or Convivial Technology for Social Revolution? Capital. Nat. Social. 2020, 32, 95-113. [CrossRef]

9. Ghisellini, P.; Cialani, C.; Ulgiati, S. A Review on Circular Economy: The Expected Transition to a Balanced Interplay of Environmental and Economic Systems. J. Clean. Prod. 2016, 114, 11-32. [CrossRef]

10. Ghisellini, P.; Ripa, M.; Ulgiati, S. Exploring Environmental and Economic Costs and Benefits of a Circular Economy Approach to the Construction and Demolition Sector. A Literature Review. J. Clean. Prod. 2018, 178, 618-643. [CrossRef]

11. Korhonen, J.; Nuur, C.; Feldmann, A.; Birkie, S.E. Circular Economy as an Essentially Contested Concept. J. Clean. Prod. 2018, 175, 544-552. [CrossRef]

12. Murray, A.; Skene, K.; Haynes, K. The Circular Economy: An Interdisciplinary Exploration of the Concept and Application in a Global Context. J. Bus. Ethics 2017, 140, 369-380. [CrossRef]

13. Geissdoerfer, M.; Savaget, P.; Bocken, N.M.P.; Hultink, E.J. The Circular Economy-A New Sustainability Paradigm? J. Clean. Prod. 2017, 143, 757-768. [CrossRef]

14. Blomsma, F.; Brennan, G. The Emergence of Circular Economy: A New Framing around Prolonging Resource Productivity. J. Ind. Ecol. 2017, 21, 603-614. [CrossRef]

15. Sauvé, S.; Bernard, S.; Sloan, P. Environmental Sciences, Sustainable Development and Circular Economy: Alternative Concepts for Trans-Disciplinary Research. Environ. Dev. 2016, 17, 48-56. [CrossRef]

16. Inigo, E.A.; Blok, V. Strengthening the Socio-Ethical Foundations of the Circular Economy: Lessons from Responsible Research and Innovation. J. Clean. Prod. 2019, 233, 280-291. [CrossRef]

17. Colombo, L.A.; Pansera, M.; Owen, R. The Discourse of Eco-Innovation in the European Union: An Analysis of the Eco-Innovation Action Plan and Horizon 2020. J. Clean. Prod. 2019, 214, 653-665. [CrossRef]

18. UNEP/Earthprint. Decoupling Natural Resource Use and Environmental Impacts from Economic Growth; UNEP/Earthprint: Nairobi, Kenya, 2011; ISBN 928073167X.

19. Corvellec, H.; Stowell, A.F.; Johansson, N. Critiques of the Circular Economy. J. Ind. Ecol. 2021. [CrossRef]

20. Padilla-Rivera, A.; Russo-Garrido, S.; Merveille, N. Addressing the Social Aspects of a Circular Economy: A Systematic Literature Review. Sustainability 2020, 12, 7912. [CrossRef]

21. Rosa, P.; Sassanelli, C.; Terzi, S. Circular Business Models versus Circular Benefits: An Assessment in the Waste from Electrical and Electronic Equipments Sector. J. Clean. Prod. 2019, 231, 940-952. [CrossRef]

22. Ghisellini, P.; Ulgiati, S. Circular Economy Transition in Italy. Achievements, Perspectives and Constraints. J. Clean. Prod. 2020, 243, 118360. [CrossRef] 
23. Interreg Europe. Sustainable Waste Management in a Circular Economy: A Policy Brief from the Policy Learning Platform on Environment and Resource Efficiency; Interreg Europe: Lille, France, 2020.

24. Mugge, R. Product Design and Consumer Behaviour in a Circular Economy. Sustainability 2018, 10, 3704. [CrossRef]

25. Nogueira, A.; Ashton, W.; Teixeira, C.; Lyon, E.; Pereira, J. Infrastructuring the Circular Economy. Energies $2020,13,1805$. [CrossRef]

26. Potting, J.; Hekkert, M.P.; Worrell, E.; Hanemaaijer, A. Circular Economy: Measuring Innovation in the Product Chain; PBL Publishers: The Hague, The Netherlands, 2017.

27. Del Vecchio, P.; Passiante, G.; Barberio, G.; Innella, C. Digital Innovation Ecosystems for Circular Economy: The Case of ICESP, the Italian Circular Economy Stakeholder Platform. Int. J. Innov. Technol. Manag. 2021, 18, 2050053. [CrossRef]

28. D'Adamo, I.; Falcone, P.M.; Martin, M.; Rosa, P. A Sustainable Revolution: Let's Go Sustainable to Get Our Globe Cleaner. Sustainability 2020, 12, 4387. [CrossRef]

29. Salvioni, D.M.; Almici, A. Circular Economy and Stakeholder Engagement Strategy. Symphonya Emerg. Issues Manag. 2020, 1, 26-44. [CrossRef]

30. Sharma, H.B.; Vanapalli, K.R.; Samal, B.; Cheela, V.R.S.; Dubey, B.K.; Bhattacharya, J. Circular Economy Approach in Solid Waste Management System to Achieve UN-SDGs: Solutions for Post-COVID Recovery. Sci. Total Environ. 2021, 800, 149605. [CrossRef]

31. Van Langen, S.K.; Vassillo, C.; Ghisellini, P.; Restaino, D.; Passaro, R.; Ulgiati, S. Promoting Circular Economy Transition: A Study about Perceptions and Awareness by Different Stakeholders Groups. J. Clean. Prod. 2021, 316, 128166. [CrossRef]

32. Falcone, P.M.; Imbert, E.; Sica, E.; Morone, P. Towards a Bioenergy Transition in Italy? Exploring Regional Stakeholder Perspectives towards the Gela and Porto Marghera Biorefineries. Energy Res. Soc. Sci. 2021, 80, 102238. [CrossRef]

33. Ncube, A.; Cocker, J.; Ellis, D.; Fiorentino, G. Biogas from Source Separated Organic Waste within a Circular and Life Cycle Perspective. A Case Study in Ontario, Canada. Environ. Sustain. Indic. 2021, 11, 100134. [CrossRef]

34. Ncube, A.; Fiorentino, G.; Colella, M.; Ulgiati, S. Upgrading Wineries to Biorefineries within a Circular Economy Perspective: An Italian Case Study. Sci. Total Environ. 2021, 775, 145809. [CrossRef]

35. Ncube, A.; Fiorentino, G.; Panfilo, C.; de Falco, M.; Ulgiati, S. Circular Economy Paths in the Olive Oil Industry: A Life Cycle Assessment Look into Environmental Performance and Benefits. In Proceedings of the 9th International Workshop on Advances in Cleaner Production, Melbourne, Australia, 26 May 2020.

36. Oliveira, M.; Zucaro, A.; Santagata, R.; Ulgiati, S. Environmental Assessment of Milk Production from Regional to Local Scale: Emergy Accounting Evaluation. J. Clean. Prod. 2021, under review.

37. Oliveira, M.; Cocozza, A.; Zucaro, A.; Santagata, R.; Ulgiati, S. Circular Economy in the Agro-Industry: Integrated Environmental Assessment of Dairy Products. Renew. Sustain. Energy Rev. 2021, 148, 111314. [CrossRef]

38. D'Adamo, I.; Falcone, P.M.; Gastaldi, M.; Morone, P. RES-T Trajectories and an Integrated SWOT-AHP Analysis for Biomethane. Policy Implications to Support a Green Revolution in European Transport. Energy Policy 2020, 138, 111220. [CrossRef]

39. Diamantis, V.; Eftaxias, A.; Stamatelatou, K.; Noutsopoulos, C.; Vlachokostas, C.; Aivasidis, A. Bioenergy in the Era of Circular Economy: Anaerobic Digestion Technological Solutions to Produce Biogas from Lipid-Rich Wastes. Renew. Energy 2021, 168, 438-447. [CrossRef]

40. Catone, C.; Ripa, M.; Geremia, E.; Ulgiati, S. Bio-Products from Algae-Based Biorefinery on Wastewater. A Review. J. Environ. Manag. 2021, 293, 112792. [CrossRef]

41. Santagata, R.; Ripa, M.; Genovese, A.; Ulgiati, S. Food Waste Recovery Pathways: Challenges and Opportunities for an Emerging Bio-Based Circular Economy. A Systematic Review and an Assessment. J. Clean. Prod. 2021, 286, 125490. [CrossRef]

42. Collela, M.; Ripa, M.; Cocozza, A.; Panfilo, C.; Ulgiati, S. Challenges and Opportunities from Circular Wastewater Management. The Case of Campania Region, Italy. J. Environ. Manag. 2021, under review. [CrossRef]

43. Morone, P.; Falcone, P.M.; Tartiu, V.E. Food Waste Valorisation: Assessing the Effectiveness of Collaborative Research Networks through the Lenses of a COST Action. J. Clean. Prod. 2019, 238, 117868. [CrossRef]

44. Dijksma, S.A.M.; Kamp, H.G.J. A Circular Economy in The Netherlands by 2050; Government of The Netherlands: The Hague, The Netherlands, 2016.

45. Ellen MacArthur Foundation. Netherlands: Green Deal; Ellen MacArthur Foundation: Cowes, UK, 2016.

46. Van Langen, S.K. Evaluating Dutch Open Innovation Policies for Key Sectors, Scuola Superiore di Studi Universitari e di Perfezionamento. Master's Thesis, Sant'Anna \& Università degli Studi di Trento, Trento, Italy, 2017.

47. Ganzevles, J.; Potting, J.; Hanemaaijer, A. Evaluatie Green Deals Circulaire Economie; Government of The Netherlands: The Hague, The Netherlands, 2016.

48. European Commission. A New Circular Economy Action Plan for a Cleaner and More Competitive Europe; European Commission: Luxembourg, 2020.

49. Kirchherr, J.; Reike, D.; Hekkert, M. Conceptualizing the Circular Economy: An Analysis of 114 Definitions. Resour. Conserv. Recycl. 2017, 127, 221-232. [CrossRef]

50. Bosman, R.; Rotmans, J. Transition Governance towards a Bioeconomy: A Comparison of Finland and The Netherlands. Sustainability 2016, 8, 1017. [CrossRef]

51. European Commission. Closing the Loop-An EU Action Plan for the Circular Economy; European Commission: Brussels, Belgium, 2015.

52. European Commission. On the Implementation of the Circular Economy Action Plan; European Commission: Brussels, Belgium, 2019. 
53. Stahel, W.R. The Circular Economy. Nature 2016, 531, 435-438. [CrossRef]

54. Klein, N.; Ramos, T.B.; Deutz, P. Circular Economy Practices and Strategies in Public Sector Organizations: An Integrative Review. Sustainability 2020, 12, 4181. [CrossRef]

55. Kalmykova, Y.; Sadagopan, M.; Rosado, L. Circular Economy-From Review of Theories and Practices to Development of Implementation Tools. Resour. Conserv. Recycl. 2018, 135, 190-201. [CrossRef]

56. Ness, D. Sustainable Urban Infrastructure in China: Towards a Factor 10 Improvement in Resource Productivity through Integrated Infrastructure Systems. Int. J. Sustain. Dev. World Ecol. 2008, 15, 288-301. [CrossRef]

57. Bocken, N.M.P.; de Pauw, I.; Bakker, C.; van der Grinten, B. Product Design and Business Model Strategies for a Circular Economy. J. Ind. Prod. Eng. 2016, 33, 308-320. [CrossRef]

58. Bauwens, T.; Hekkert, M.; Kirchherr, J. Circular Futures: What Will They Look Like? Ecol. Econ. 2020, 175, 106703. [CrossRef]

59. Webster, K. The Circular Economy: A Wealth of Flows; Ellen MacArthur Foundation Publishing: Cowes, UK, 2017 ; ISBN 0992778468.

60. Inostroza, L.; Zepp, H. The Metabolic Urban Network: Urbanisation as Hierarchically Ordered Space of Flows. Cities 2021, 109, 103029. [CrossRef]

61. Schumpeter, J.A. The Analysis of Economic Change. Rev. Econ. Stat. 1935, 17, 2-10. [CrossRef]

62. Schumpeter, J.A. Business Cycles; McGraw-Hill: New York, NY, USA, 1939; Volume 1.

63. Hachem, H.M. Innovation, Dynamics and the Myths about Knowledge, Technology and R\&D-Driven Economic Growth: An Evolving Network Model. J. Innov. Econ. Manag. 2017, 23, 13-32.

64. Wirkierman, A.L.; Ciarli, T.; Savona, M. Varieties of European National Innovation Systems; ISIGrowth: Falmer, UK, 2018.

65. OECD. National Innovation Systems; OECD Publications: Paris, France, 1997.

66. Casadella, V.; Uzunidis, D. National Innovation Systems of the South, Innovation and Economic Development Policies: A Multidimensional Approach. J. Innov. Econ. Manag. 2017, 23, 137-157. [CrossRef]

67. Ponsiglione, C.; Quinto, I.; Zollo, G. Regional Innovation Systems as Complex Adaptive Systems: The Case of Lagging European Regions. Sustainability 2018, 10, 2862. [CrossRef]

68. Leick, B.; Gretzinger, S. Knowledge Sharing for Business Cluster and Business Network Contexts. J. Innov. Econ. Manag. 2020, 33, 1-8. [CrossRef]

69. Tuitjer, G.; Küpper, P. How Knowledge-Based Local and Global Networks Foster Innovations in Rural Areas. J. Innov. Econ. Manag. 2020, 33, 9-29. [CrossRef]

70. Mina, A.; Bascavusoglu-Moreau, E.; Hughes, A. Open Service Innovation and the Firm's Search for External Knowledge. Res. Policy 2014, 43, 853-866. [CrossRef]

71. Kühl, C.; Bourlakis, M.; Aktas, E.; Skipworth, H. How Does Servitisation Affect Supply Chain Circularity?-A Systematic Literature Review. J. Enterp. Inf. Manag. 2019, 33, 703-728. [CrossRef]

72. Pierre, A.; Fernandez, A.-S. Going Deeper into SMEs' Innovation Capacity: An Empirical Exploration of Innovation Capacity Factors. J. Innov. Econ. Manag. 2018, 25, 139-181. [CrossRef]

73. Dieckmann, E.; Sheldrick, L.; Tennant, M.; Myers, R.; Cheeseman, C. Analysis of Barriers to Transitioning from a Linear to a Circular Economy for End of Life Materials: A Case Study for Waste Feathers. Sustainability 2020, 12, 1725. [CrossRef]

74. Bianchini, A.; Rossi, J.; Pellegrini, M. Overcoming the Main Barriers of Circular Economy Implementation through a New Visualization Tool for Circular Business Models. Sustainability 2019, 11, 6614. [CrossRef]

75. Feng, K.; Lam, C.-Y. An Overview of Circular Economy in China: How the Current Challenges Shape the Plans for the Future. Chin. Econ. 2021, 54, 355-371. [CrossRef]

76. Salmenperä, H.; Pitkänen, K.; Kautto, P.; Saikku, L. Critical Factors for Enhancing the Circular Economy in Waste Management. J. Clean. Prod. 2021, 280, 124339. [CrossRef]

77. Henriques, J.; Ferrão, P.; Castro, R.; Azevedo, J. Industrial Symbiosis: A Sectoral Analysis on Enablers and Barriers. Sustainability 2021, 13, 1723. [CrossRef]

78. Shooshtarian, S.; Caldera, S.; Maqsood, T.; Ryley, T. Using Recycled Construction and Demolition Waste Products: A Review of Stakeholders' Perceptions, Decisions, and Motivations. Recycling 2020, 5, 31. [CrossRef]

79. Gusmerotti, N.M.; Testa, F.; Corsini, F.; Pretner, G.; Iraldo, F. Drivers and Approaches to the Circular Economy in Manufacturing Firms. J. Clean. Prod. 2019, 230, 314-327. [CrossRef]

80. Lundvall, B.-Å. National Innovation Systems-Analytical Concept and Development Tool. Ind. Innov. 2007, 14, 95-119. [CrossRef]

81. Lundvall, B.-Å.; Johnson, B.; Andersen, E.S.; Dalum, B. National Systems of Production, Innovation and Competence Building. Res. Policy 2002, 31, 213-231. [CrossRef]

82. Corredoira, R.A.; Goldfarb, B.D.; Shi, Y. Federal Funding and the Rate and Direction of Inventive Activity. Res. Policy 2018, 47, 1777-1800. [CrossRef]

83. Kuckartz, U. Qualitative text analysis: A systematic approach. In Compendium for Early Career Researchers in Mathematics Education; Springer: Cham, Switzrland, 2019; pp. 181-197.

84. Bengtsson, M. How to Plan and Perform a Qualitative Study Using Content Analysis. Nurs. Open 2016, 2, 8-14. [CrossRef]

85. Krippendorff, K. Content Analysis: An Introduction to Its Methodology; Sage Publications: New York, NY, USA, 2018; ISBN 1506395678.

86. Silverman, D. Interpreting Qualitative Data; Sage Publications: New York, NY, USA, 2015; ISBN 147391664X. 
87. Scandurra, G.; Thomas, A.; Passaro, R.; Bencini, J.; Carfora, A. Does Climate Finance Reduce Vulnerability in Small Island Developing States? An Empirical Investigation. J. Clean. Prod. 2020, 256, 120330. [CrossRef]

88. Schoonen, W. Ons Systeem van Kennisproductie Loopt Vast Door Te Complexe Geldstromen. Trouw, 1 December 2019.

89. Mhatre, P.; Panchal, R.; Singh, A.; Bibyan, S. A Systematic Literature Review on the Circular Economy Initiatives in the European Union. Sustain. Prod. Consum. 2021, 26, 187-202. [CrossRef]

90. Wang, Y.; Zhi, Q. The Role of Green Finance in Environmental Protection: Two Aspects of Market Mechanism and Policies. Energy Procedia 2016, 104, 311-316. [CrossRef]

91. Falcone, P.M.; Morone, P.; Sica, E. Greening of the Financial System and Fuelling a Sustainability Transition: A Discursive Approach to Assess Landscape Pressures on the Italian Financial System. Technol. Forecast. Soc. Chang. 2018, $127,23-37$. [CrossRef]

92. Zhang, D.; Zhang, Z.; Managi, S. A Bibliometric Analysis on Green Finance: Current Status, Development, and Future Directions. Financ. Res. Lett. 2019, 29, 425-430. [CrossRef]

93. Taghizadeh-Hesary, F.; Yoshino, N. The Way to Induce Private Participation in Green Finance and Investment. Financ. Res. Lett. 2019, 31, 98-103. [CrossRef]

94. Bieseman, H.; Kamas, F. Evaluatie van Het Green Deal Instrument; Departement Omgeving: Brussels, Belgium, 2019. 